\title{
Race and Contention in Twenty-First Century U.S. Media
}

\author{
Edited by Jason A. Smith \\ and Bhoomi K. Thakore
}

First published 2016

ISBN 13:978-1-138-93715-4 (hbk)

ISBN 13:978-1-315-67642-5 (ebk)

\section{Chapter 3}

\section{New Media and New Possibilities}

The Online Engagement of Young Black Activists

Nathan Jamel Riemer

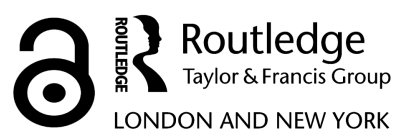




\title{
3 New Media and New Possibilities The Online Engagement of Young Black Activists
}

\author{
Nathan Jamel Riemer
}

On July 14, 2013, the day after George Zimmerman was exonerated from the murder of Trayvon Martin, a group of young Black activists, who now constitute the Black Youth Project 100 (BYP100), ${ }^{1}$ video recorded a collectively written response and began circulating it via their social media accounts. The fact that the immediate reaction of these activists was to independently produce a piece of media is telling. It not only tells of the changes in the media landscape brought on by the emergence of new media ${ }^{2}$ (that made it possible for the BYP100 to input their collective voice into a public conversation that traditional mass media would likely not have invited them to participate), but it also speaks to these activists' understanding of the use of new media as a method of political engagement. The high speed, ease, and low cost at which individuals and organizations are now able to independently produce and circulate media are affordances that are unique to the rise of new media. This is quite different from the production and circulation processes of traditional mass media. Consequently, the long-standing dependent relationship between activists, who wish to interject alternative framings into mainstream conversations, and traditional mass media, has been altered. Activists no longer require traditional mass media coverage in order to fulfill vital goals of social movement work (e.g., mobilization, scope enlargement, and validation), and activists that do not gain traditional mass media coverage no longer necessarily go unknown to the broader public.

The value of traditional mass media to activists and social movements, both past and present, is undeniable. However, the level of dependence marginal voices had on traditional mass media outlets has been reduced by the exponential increase in media channels brought on by the emergence of new media and social media platforms. New media and their attendant technologies have made it possible for any activist or network of activists who have Internet access via phone, computer, or tablet, and a basic level of computer literacy to engage, organize, and mobilize. The ability to produce and circulate media is now widely shared; traditional mass media are no longer the only means of communicating to the public.

Many people, both laymen and scholars alike, may not believe that these digitally enabled acts constitute meaningful political engagement. They may disregard such behavior by pejoratively labeling it as "slacktivism" and, 


\section{Nathan Jamel Riemer}

therefore, largely or completely ineffectual. However, some have a broader understanding of political engagement and see such online activity as a new norm in activist engagement and a form of participatory politics. Broadly defined, participatory politics are "ways young people seek to exert voice and influence on issues of public concern by taking advantages of new opportunities available through the use of new media" (Rogowski \& Cohen, 2015, p. 49). Using data from a case study of the BYP100, this chapter highlights the centrality of new media in the activism and development of the BYP100 by focusing on two digitally enabled acts of participatory politics, each drawing attention to the marginalization of young Black Americans.

In what follows, I first highlight scholarship that has addressed the historic relationship between activist movements and the mass media. This scholarship makes clear the longstanding importance of traditional mass media to social movement work. New media scholarship, however, points to a number of affordances brought on by the expanding media landscape that have complicated this relationship and brought about new possibilities for engagement: participatory politics. I will then return to the work of the BYP100 to exemplify ways in which young Black people are making use of new media to publicly voice their grievances on their terms.

\section{A Changing Media Landscape}

\section{Traditional Mass Media, New Media, and New Possibilities}

Whereas protest actions were once each bounded by a unique place and time, with activists airing their grievances directly to local power holders as bystanders watched, the rise of traditional mass media exploded the boundaries of protest activities allowing the number of people to be exposed to the communicated grievances to be nearly limitless. Consequently, media portrayals have become the primary point of contact between those who choose to contest the distribution and functioning of power, the broader public, and power holders. As Koopmans claimed, "it is no longer the co-present public that counts most, but the mass audience that sits at home and watches or reads the media coverage of the demonstration" (2004, p. 368). For this reason, activists and social movements have historically been dependent on traditional mass media in order to gain the attention of the mass public (Gamson \& Wolfsfeld, 1993; Snow, Rochford, Worden, \& Benford, 1986). This dependence has frequently led activists to structure their activities and messages in particular ways in efforts to gain traditional media coverage (Cottle, 2008; Lunceford, 2012; Wolfsfeld, 1984).

Referring to traditional mass media, political scientist Joachim Raschke stated, "A movement that does not make it into the media is non-existent" (as quoted in Rucht, 2004, p. 29). While this statement may no longer hold true due to the affordances new media have brought to the media landscape, scholars continue to highlight the significance of traditional mass media for social movement causes (Cottle, 2008; Graeff, Stempeck, \& Zuckerman, 
2014). For example, traditional mass media outlets across the country, and at points across the world, aired the protest actions that took place in Oakland, Miami, Detroit, Ferguson, and New York City of those who contested the murders of Oscar Grant, Trayvon Martin, Renisha McBride, Michael Brown, and Eric Garner. Although the role of new media in the coverage and spread of these activist actions is undeniable, the televised airing of these protests amplified their reach allowing the actions and the grievances of the protesters who took to the streets to be visible to a larger audience than they would have reached otherwise. This mass media amplification contributed to eliciting not only local responses but also national and sometimes international responses to these events and their causes. It is important to keep in mind that the emergence of new media did not create a parallel media landscape that operates exclusively from traditional mass media. There is constant and complex interaction between traditional mass media and new media (Asur, Huberman, Szabo, \& Wang, 2011: Graeff et al., 2014).

Graeff, Stempeck, and Zuckerman (2014) nicely tease out this interaction by looking at the development of traditional mass media and new media coverage of the murder of Trayvon Martin. They found that local news outlets initially covered the murder of Trayvon Martin; it then received coverage by two national news outlets (Reuters and CBS This Morning). This national coverage was followed by the further spread of the story through new media outlets (e.g., Change.org and Twitter). The authors stated,

We believe the national attention brought to the story through broadcast media allowed groups like the Black Youth Project to amplify stories to their online communities, and informed actors like [Kevin] Cunningham ${ }^{3}$ who launched campaigns like the Change.org petition. Without the initial coverage on newswires and television, it is unclear that online communities would have known about the Trayvon Martin case and been able to mobilize around it ... The power of social media in the context of stories like Trayvon Martin's, where a local tragedy sparked a national debate, may be less about bringing these stories to light than about shaping their arc.

(Graeff et al., 2014, pp. 21-22)

Although the story of Trayvon Martin broke on traditional media, new media played a significant agenda-setting function. Activists organized protest actions such as the Million Hoodies March that kept Martin's story in the public eye. Additionally, online communities like the Black Youth Project utilized social media to insist that Martin's death be understood as a function of a race-based society. The large amount of online support for this alternative framing resulted in it being indelibly wed to the story of Martin's murder in ongoing public discourse across all forms of media. The impact of new media activity on the unfolding of Trayvon Martin's story provides an example of new media-traditional mass media interaction. It also shows 


\section{Nathan Jamel Riemer}

the vulnerabilities of traditional media's gatekeeping and agenda setting to new media influences (Cottle, 2008; Rosen, 2009).

Traditional mass media gatekeepers can be bypassed as online new media platforms are used as alternative media (Postmes \& Brunsting, 2002). Through these platforms, potentially, millions of people can be reached without the aid of traditional mass media outlets (Friedland \& Rogerson, 2009). Activists can now independently produce media, circulate it via their social network accounts or websites, and, thereby, input counternarratives and new voices into public conversations (Bimber, Flanagin, \& Stohl, 2005; Cottle, 2008; Graeff et al., 2014). The multiple sources of information and the multiple means by which information can now be produced, shared, and accessed have weakened the gatekeeping ability of traditional mass media elites (Bimber, 2003; Williams \& Delli Carpini, 2000). New media have reshaped the relationship between social movements and activists and mass media (Bimber et al., 2005; Friedland \& Rogerson, 2009).

Scholars who challenge starry-eyed views of new media insist that new media has its own set of gatekeepers that affect the level of visibility of particular messages. "Even in the seemingly non-hierarchical internet, providers, internet browsers, and search engines pre-structure access to information on the web in such a way that certain sites are more easily and more frequently accessed than they would have been in the absence of such gatekeeping" (Koopmans, 2004, pp. 372-373). New media is not a level and open playing field. While almost anyone has the opportunity to speak, everyone is not equally positioned to be heard (Hindman, 2008). Others worry that the communicative affordances of new media allow for the ease of false information to be vastly spread (Newman, 2011). Still others are concerned that the increased sources for media content and the increased ability to select from them will lead people to filter the information they consume in a manner that simply reinforces their opinions and neglects alternative viewpoints (Sunstein, 2009).

\section{Slacktivism, Participatory Politics, and the BYP100}

The addition of new media to the media landscape has certainly altered the relationships among traditional mass media, activists, and the broader public, and facilitated new means and modes of political engagement, organization, and mobilization. The affordances of new media can be leveraged to support offline protest actions, create online versions of traditional forms of engagement, or produce novel forms of participation that occur entirely online (Christensen, 2011; Earl \& Kimport, 2011; Jordan \& Taylor, 2004). Some criticize these new forms of online activism and pejoratively label them as "slacktivism." Rather than understanding the ease of engagement as a boon for political participation, they question whether online activism is a 
meaningful and impactful way to achieve real political outcomes (Hindman, 2009; Morozov, 2009; Shulman, 2009).

Critics also claim that online activism may reduce participation in offline forms of engagement, which they believe to be more efficacious efforts (Gladwell, 2010; Lee \& Hsieh, 2013; Morozov, 2009). The worry is that people may see online and offline forms of participation as equivalent and, therefore, when deciding how to become politically engaged they will opt for online forms of engagement because they are easier and more convenient than offline participation. When people can forward a link, change their profile pictures, post videos, or tweet in order to express their political viewpoints, attempt to leverage power holders, or expose others to civic and political matters, they will do that rather than stage a sit-in, stand in line to vote, walk in a march, or gather signatures for an offline petition (Morozov, 2009). After engaging in these low-effort online actions, individuals will feel content with their level of participation and feel no need to take part in offline efforts (Lee \& Hsieh, 2013). Consequently, Morozov (2009) claims that slacktivism is "the ideal type of activism for a lazy generation."

Scholars of the MacArthur Research Network on Youth and Participatory Politics (YPP), however, have a broader understanding of political engagement: "Our conceptualization of politics extends beyond the electoral focus that often dominates literature about political participation and includes a broad array of activities undertaken by individuals and groups to influence how the public sets agendas and addresses issues of public concern" (Kahn, Middaugh, \& Allen, 2014, p. 6). Scholars of the YPP network would call the BYP100's video response an example of participatory politics.

Young people engage in participatory politics by collecting and consuming information distributed through non-traditional sources, commenting on or providing feedback on political issues through digital means, circulating information and opinions, producing original online content and mobilizing their communities and members of their digital networks.

(Rogowski \& Cohen, 2015, p. 49)

Traditionally, voting rates have been the main, and often sole, measure of political engagement. This measure has never captured the diversity of ways in which people engage in efforts to impact the distribution of power and challenge policy; and has particularly neglected the political lives of young people who have historically had low voter turnout rates or are ineligible to vote due to age. This problem of measurement has fueled public discourse regarding the political apathy of young people. However, when specifically assessing the political engagement of young people, researchers have found that " 41 percent of young people engage in at least one act of participatory politics, which is roughly equal to the 44 percent who engage in other acts of politics. This suggests that participatory politics make up a substantive 
part of youth political activity" (Kahn et al., 2014, p. 18). Interestingly, engagement in participatory politics is nearly equal across racial groups; this is in stark contrast to voting rates across race (Cohen, Kahn, Bowyer, Middaugh, \& Rogowski, 2012). The growing accessibility of new media is facilitating increased opportunities for activists, in groups or as individuals, to engage in various forms of participatory politics. In doing so, those who do not fall within "conventional elite groups" are finding new modes of exerting agency and influence in the political realm (Kahn et al., 2014).

\section{Data and Methods}

The collection of the data that are presented throughout this chapter began at the Beyond November Movement Convening (BNMC), which was hosted by the Black Youth Project (BYP) in Itasca, Illinois, during the July 12-14, 2013, weekend. The BYP launched in 2005 as a national research project led by Cathy Cohen of the University of Chicago. It "examined the attitudes, resources, and culture of African American youth ages 15 to 25, exploring how these factors and others influence the decision-making, norms, and behavior of Black youth" (www.Blackyouthproject.com/about/). In an effort to make data from the BYP available to a larger public Cathy Cohen took it online and created Blackyouthproject.com. The BYP website hosts survey data and corresponding reports, a database of youth organizations across the nation, a database of rap lyrics compiled from 20 years of releases, and a blog populated by an array of Black youth contributors, among a number of other resources for youth, educators, activists, and scholars. The work of the BYP has three guiding concepts:

KNOWLEDGE: We are committed to producing research about the ideas, attitudes, decision making, and lived experiences of Black youth, especially as it relates to their political and civic engagement.

VOICE: Unlike any other organization, we amplify the perspectives of young Black people daily without censorship or control. We have built a space on the Internet where Black youth can speak for themselves about the issues that concern them.

ACTION: Informed with culturally-specific knowledge, we will work to mobilize Black youth and their allies to make positive change and build the world within which they want to live. (http://research.Black youthproject.com/about-us/)

It was in the spirit of the third guiding concept that the BYP came to organize the BNMC, which brought together young Black activists from across the nation.

I was in attendance as a note taker tasked with documenting the event for the BYP. I participated in the majority of convening activities; conversing 
while also documenting the event with field notes. I also attended a portion of a BYP100 convening in Washington, DC. Immediately following the BNMC, I began sitting in on many of the BYP100's conference calls. My permission to attend these calls came from the cochairs of the BYP100. In addition to my notes from the field and on the phone I conducted 32 semistructured interviews with members of the BYP100 and those who organized the BNMC. Last, I also gathered data for this project by following the BYP100's Twitter profile and YouTube channel.

\section{The Zimmerman Verdict: A Racial Crisis}

As the second day of the BNMC was coming to a close, the jury for the George Zimmerman trial reached a verdict. A stream of the trial coverage was projected on the conference room's overhead screen. The room filled with nerve-wracking anticipation and near silence as everyone present stood hand-in-hand in solidarity and awaited the verdict. As the not guilty verdict was read participants yelled in agony and anger. Many broke down in tears. Few remained silent.

It was "a national disaster for the Black community, it may not have been a hurricane or a tornado, but for all intents and purposes, the Zimmerman verdict and that whole process really was a natural disaster for our community just in the way that it affected each of us so deeply," stated one member of the BYP100. The fact that George Zimmerman was not held accountable for Trayvon Martin's death was not just traumatic for his family and friends. For many young Black people beyond Trayvon Martin's immediate social circles "it basically was a statement from the state and all these people saying 'Black life doesn't matter,'” stated one BYP100 member. This moment was one that heightened these activists' sense of their racial position in this country.

\section{\#BYP100 Responds}

The next morning the members of the BYP100 squeezed in close in order to fit within the scope of a video camera. As everyone stood in silence, two members of the BYP100 seated at center, one female and the other male, took turns reading portions of the following statement from an iPad.

To the Family of Brother Trayvon Martin and to the Black Community: May this statement find us in the spirit of peace and solidarity.

We know that justice for Black life is justice for humanity.

Our hope and community was shaken through a system that is supposed to be built on freedom and justice for all. We are your sons and daughters. We are the marginalized and disenfranchised. We are one hundred next generation leaders. We are the Black Youth Project 100 (BYP100). 
We see the hopelessness of a generation that has been broken trying to find its place in this world. We understand that we need to turn anger into action and pain into power.

As we waited to hear the verdict, in the spirit of unity, we formed a circle and locked hands. When we heard "not guilty," our hearts broke collectively. In that moment, it was clear that Black life had no value. Emotions poured out-emotions that are real, natural and normal, as we grieved for Trayvon and his stolen humanity. Black people, WE LOVE AND SEE YOU. We mourn, but there's hope as long as love endures.

Trayvon was manifested from ancestral excellence. The salt water falling from our eyes now, is not different from the salt water we were trafficked on then. If the soil of the United States could speak, before saying a word it would cough up our blood. Choking frantically, crustcurdling with the gore of a oppressed peoples it has been force-fed. White supremacy has water-boarded it with the remnants of its genocide of us. This moment reminds us that we can't look to others to see our value but we have to recognize our own value. In spite of what was said in court, what verdict has been reached, or how hopeless we feel, Trayvon did NOT die in vain. A mother should never have to bury her son. However, his death will serve as the catalyst of a new movement where the struggle for justice will prevail.

Instead of a moment of silence, we raise our voices together. As Audre Lorde said, "our silence will NOT PROTECT US." We are young leaders standing on the shoulders of our ancestors, carrying the historical trauma embedded in a legal system that will NOT PROTECT US. We are the legacy of Black resilience that compels us to fight for our lives.

We continue to call out Black Love, Black Power and Black is Beautiful in the face of continued devaluation of Black life. We affirm a love of ALL Black life, no matter if we are in hoodies or business suits, incarcerated or in boardrooms, on welfare or in the WNBA, on the corner or in the White House. We declare the fundamental value, beauty and power of ALL Black people. The poet Claude McKay once said, "Though far outnumbered, let us show us brave ... we'll face the murderous, cowardly pack. Pressed to the wall, dying, but fighting back!" JUSTICE FOR TRAYVON.

Within two days of the video being produced and posted to the BYP website and the social media sites of the BYP100 members, it was reposted and further circulated online by such noted websites as HuffingtonPost.com, Ebony.com, and AlJazeera.com. The amount of coverage that the BYP100 video received by corporate digital media sites caught the attention of many and helped the video garner 23,000 views within the first few days.

On account of the video's release, the BYP100 gained a significant online media presence long before it had established a formal organizational 
structure. The online media attention created an air of organizational development that was not yet present. For example, shortly after the video's release, theRoot.com expressed interest in doing feature stories on the "leaders" of the organization. However, while the BYP100 left the BNMC with plans and fervor, "the only structural thing at the time was a semblance of a commitment to a coordinating council," noted one member of the BYP100. Additionally, just a few weeks after the BNMC, five members of the BYP100 went to Florida to attend an event organized by the Dream Defenders and Power U, founded in 2012 and 1998, respectively. The event was a rally in support of the Take Over Florida campaign in which members of the Dream Defenders occupied the Florida governor's office in Tallahassee. When the attending BYP100 members reported back to the larger group regarding their participation, one of them exclaimed, "BYP100 was an organization in everyone's eyes! It was a real thing. A representative of Black youth action in the country." This was prior to the BYP100 formally implementing an organizational structure or engaging in any public collective action or campaigning beyond the release of their video response to the Zimmerman verdict.

\section{BYP100: Black Youth, Black Police, and Transformative Justice}

On March 12, 2014, the BYP100 released another video. It was recorded during a BYP100 convening that was hosted by Princeton University's Center for African American Studies. The video was posted to the BYP100's YouTube account. It captured footage of a dialogue between a Black police officer and some members of the BYP100 on March 8, 2014. The officer pulled over a car carrying a number of BYP100 members as they were leaving the Princeton University campus after attending a small party for the organization and heading back to their hotel. The officer cited a broken taillight as the reason for the stop. The taillight, however, was found to be in working condition once the car was stopped and further inspected. Before letting the BYP100 members go, the police officer reportedly asked where they were heading and said that he would beat them there. When they arrived, he was sitting in his patrol car in front of their hotel. A conversation ensued and was videotaped by a member of the BYP100.

The conversation dealt with issues of the criminalization of Black youth. Members of the BYP100 approached the police officer as he sat in his vehicle and attempted to explain to him how they, as young Black people, felt criminalized by police through racial profiling. One member of the BYP100 explained to the officer,

You guys have a responsibility to protect and serve and we just really want you guys to protect and serve. As youth-as Black youth we don't feel like we get that level of protection. We don't get that benefit of the doubt that like white students running around Princeton campus get. 
The police officer tried to convey that profiling and criminalizing members of the BYP100 was not his intention when he stopped their car. One BYP100 member recounted the interaction with the police officer in a blog post.

After our party, a group of us were pulled over by a Black police officer. The tension was high, Black youth at a white university, all of whom have an inherent distrust of the police, and a system that has an inherent distrust of Black youth. Although we were doing nothing wrong we know all too well the realities of the Trayvon Martins of the world and that we are often "guilty until proven innocent." The misunderstanding was able to evolve into a teachable moment for both parties where race issues and the lack of safety Black youth feel was discussed. We are on our way to creating policies that address stop \& frisk and the shoot first law, but our first accomplishment I think, is sparking those conversations the world is afraid to have. Conversations that build bridges.

(Tiara, 2014)

The Princeton video, like the video response to the Zimmerman verdict, quickly gained the attention of traditional mass media outlets. It was first picked up by theRoot.com and reposted in a short article on March 18, 2014. It was then reposted on BET.com, and picked up by other noted websites such as Bossip.com and UrbanCusp.com. Members of the BYP100 did not pitch this video to media outlets, yet it received nearly 130,000 views.

The affordances of new media made it possible for the BYP100 to share this experience with a large audience. Most likely, this police encounter would never have come to the attention of anyone other than the participants otherwise. The drama and sensationalism that often draws the attention of traditional mass media news coverage was absent. Because the BYP100 both produced and distributed this piece of media on their own, they had sole control of its original framing. The BYP100 framed this police encounter as an example of transformative justice rather than simply highlighting the negative aspects of the interaction. Fresco Steez, a member of the BYP100, provided the following definition of transformative justice: "A means to transforming the systems, institutions, and environments that we interact with on a daily basis. So they are no longer systemically violent" (BYP100, 2014). This framing created a counternarrative to most publicized interactions between police and young Black people. Consequently, when readers came across theRoot.com's headline, "Black Youths Attending Princeton Conference Pulled Over by Police, Then This Happened ...," or UrbanCusp. com's headline, "Watch: Youth Activist Group BYP100 Members Pulled Over by Princeton Police," many were likely surprised to see a peaceful conversation between a police officer and members of the BYP100. Additionally, readers on Bossip.com were likely made equally curious by the counternarrative when seeing the headline "A Lil Positivity: Black Youths At Princeton Have 'Healthy Dialogue' With Cop Who Racially Profiled Them [Video].” 


\section{Discussion and Conclusion}

The BYP100's claims of marginalization, questioning of a justice system supposedly "built on freedom and justice for all," and feelings of the criminalization of Black youth (\#CriminalizedLives) that were expressed in the videos discussed in this chapter are not sentiments unique to the BYP100. Rather, these claims reflect a widespread sense of marginalization and political alienation among many young Black Americans (Cohen, 2010; Rogowski \& Cohen, 2015). Cohen's work notes that over $60 \%$ of young Black Americans reported that they agreed with the statement "it is hard for young Black people to get ahead because they face so much discrimination" (2010, p. 121). Young Black Americans also expressed "the belief that they are relatively powerless to influence government (Rogowski \& Cohen, 2015, p. 55). And, unfortunately, only $11 \%$ of young Black Americans claimed that racism would very likely be eliminated in their lifetime. Even after the 2012 presidential election of Barack Obama, 69\% of young Black Americans reported, "Racism remains a major problem" (Cohen, 2010, p. 222).

Although these sentiments loom large for young Black Americans, and extant scholarship demonstrates a particular racial experience wherein Black Americans are at a structural deficit (e.g., Alexander, 2012; Pager, 2007; Massey \& Denton, 1993), declarations of racial inequality are consistently delegitimized by an American ideology of colorblindness. Colorblindness vehemently restricts claims of racism as a source of racial disparity and instead "explains contemporary racial inequality as the outcome of nonracial dynamics" (Bonilla-Silva, 2010, p. 2). Those who adhere to colorblind ideology paint traumatic events such as the murder of Trayvon Martin, ${ }^{4}$ the unpunished beating of Rodney King, and Hurricane Katrina and her aftermath as unfortunate incidents, tough justice, isolated events, or an unprecedented natural disaster. The ideology of colorblindness refuses to concede that such events exemplify the "marginalization and disenfranchisement" the BYP100 assert. But these are not novel atrocities. The ubiquity of new media and its attendant technologies have created a context wherein firsthand footage captured and circulated across the Internet by amateurs demonstrates that although months and miles may sometimes separate the most popularized incidents of race-based brutality, each is a point in a pattern. This pattern demonstrates a social structure in which race matters. The lived experience of young Black Americans is in direct contrast to colorblind ideology. Consequently, mainstream racial discourse is reluctant to Black youth voicing their grievances; and mainstream media, which has long been charged with supporting the status quo and the interests of the elite (Herman \& Chomsky, 1988; McLeod \& Detenber, 1999), is most often not a viable outlet.

New media, on the other hand, provide ample opportunities for grievances regarding racial inequality to be publicly voiced and racial inequality publicly challenged. This is clear to activists such as the BYP100 and 


\section{Nathan Jamel Riemer}

others who feel that their voices are unwelcomed or unheard in traditional mass media. "It's power," stated one member of the BYP100 describing new media:

We've seen lots of movements whether we want to talk about Occupy the Hood or we want to talk about the movement with Trayvon Martin and the movement with Marissa Alexander. All of these movements should be waged on and offline and most of these movements are being led by young people of color and so I think social media is very critical and I think social media presents an opportunity to folks who didn't necessarily have the financial means or didn't necessarily have the resources that other people with traditional power used to have, but I think that social media gives people especially people who have traditionally been marginalized the power to make a footprint.

Other BYP100 members referred to new media as "a platform to the masses"; and explained that it allows you to post "your message in your terms" and "have a voice in some incredible way." Even so, BYP100 members were sure to express that traditional offline organizing and activism is still vital to social movement work. It is imperative to have an "onlineoffline connection."

By providing individuals and organizations the ability to relatively easily produce and distribute their own media, the emergence of new media has made it possible for the voices of activists, such as the BYP100, to effectively engage in media framing and agenda-setting processes. The traditional media landscape did not lend itself well to the inclusion of marginalized voices and alternative viewpoints. The relatively small number of media outlets created an intensity of gatekeeping pressures, as media producers aimed, and continue to aim, to gain the biggest percentage of the mainstream audience. The addition of new media to the media landscape now provide increased opportunity for marginalized voices to actively influence the variety of media, frames, and social issues that contribute to public discourse by taking an active part in independently producing and circulating digital content. In general, Black youth have higher rates of online political activity than their White and Latino peers (Rogowski \& Cohen, 2015). The BYP100's videos addressed herein exemplify this type of digitally enabled participatory politics.

\section{Notes}

1. The BYP100 is a national social movement organization of young Black activists. See BYP100.org.

2. While definitions of "new media" are many, in this chapter the term will refer to digital media that are created with and accessed through the use of computing technologies. Such media are generally characterized by their low barriers to production and distribution and allow for interactive, two-way communication. 
3. Kevin Cunningham is the Howard University alum that began a Change.org petition on March 8, 2012, after viewing the Reuters piece on Trayvon Martin's murder. The petition received more than a million signatures.

4. Due to space, I use Trayvon Martin's name to call attention to his own untimely death and also to represent the numerous other unarmed Black people that have been killed by armed police officers and vigilantes.

\section{References}

Alexander, M. (2012). The new Jim Crow: Mass incarceration in the age of colorblindness. New York, NY: The New Press.

Asur, S., Huberman, B., Szabo, G., \& Wang, C. (2011). Trends in social media: Persistence and decay. Retrieved from http://www.hpl.hp.com/research/scl/papers/ trends/trends_web.pdf.

Bimber, B. (2003). Information and American democracy: Technology in the evolution of political power. Cambridge, UK: Cambridge University Press.

Bimber, B., Flanagin, A. J., \& Stohl, C. (2005). Reconceptualizing collective action in the contemporary media environment. Communication Theory, 15, 365-388.

Black Youth Project 100 (BYP100). (2014, March 26). BYP100 methods of social change hangout [Video file]. Retrieved from https://www.youtube.com/ watch? $=$ XIHEyba1vzw\&feature=youtu.be.

Bonilla-Silva, E. (2010). Racism without racists: Color-blind racism and the persistence of racial inequality in the United States. Lanham, MD: Rowman \& Littlefield.

Christensen, H. S. (2011). Political activities on the Internet: Slacktivism or political participation by other means? First Monday, 16, 2-7.

Cohen, C. J. (2010). Democracy remixed: Black youth and the future of American politics. Oxford, UK: Oxford University Press.

Cohen, C. J., Kahne, J., Bowyer, B., Middaugh, E., \& Rogowski, J. (2012). Participatory politics: New media and youth political action. Retrieved from http://ypp. dmlcentral.net/sites/all/files/publications/YPP_Survey_Report_FULL.pdf.

Cottle, S. (2008). Reporting demonstrations: The changing media politics of dissent. Media Culture Society, 30(6), 853-872.

Earl, J., \& Kimport, K. (2011). Digitally enables social change: Activism in the Internet age. Cambridge, MA: MIT Press.

Friedland, J., \& Rogerson, K. (2009). How political and social movements form on the Internet and how they change over time. Institute for Homeland Security Solutions.

Gamson, W. A., \& Wolfsfeld, G. (1993). Movements and media as interacting systems. Annals of the American Academy of Political and Social Science, 528, 114-125.

Gladwell, M. (2010, October 4). Small change: Why the revolution will not be tweeted. The New Yorker. Retrieved from http://www.newyorker.com/ reporting/2010/10/04/101004fa_fact_gladwell.

Graeff, E., Stempeck, M., \& Zuckerman, E. (2014). The battle for “Trayvon Martin”: Mapping a media controversy online and off-line. First Monday, 19(2-3). Retrieved from http://firstmonday.org/ojs/index.php/fm/article/view/4947.

Herman, E. S., \& Chomsky, N. (1988). Manufacturing consent: The political economy of the mass media. New York, NY: Pantheon Books. 


\section{Nathan Jamel Riemer}

Hindman, M. (2008). The myth of digital democracy. Princeton, NJ: Princeton University Press.

Jordan, T., \& Taylor, P. (2004). Hacktivism and cyberwars: Rebels with a cause. London, UK: Routledge.

Kahn, J., Middaugh, E., \& Allen, D. (2014). Youth, new media, and the rise of participatory politics. Oakland, CA: Youth and Participatory Politics Research Network.

Koopmans, R. (2004). Movements and media: Selection processes and evolutionary dynamics in the public sphere. Theory and Society, 33(3-4), 367-391.

Lee, Y.-H., \& Hsieh, G. (2013). Does slacktivism hurt activism?: The effects of moral balancing and consistency in online activism. CHI'13 Proceedings of the SIGCHI Conference on Human Factors in Computing Systems (pp. 811-820). New York, NY: ACM.

Lunceford, B. (2012). Naked politics: Nudity, political action, and the rhetoric of the body. Lanham, MD: Lexington.

Massey, D., \& Denton, N. (1993). American apartheid: Segregation and the making of the underclass. Cambridge, MA: Harvard University Press.

McLeod, D. M., \& Detenber, B. H. (1999). Framing effects of television news coverage of social protest. Journal of Communication, 49(3), 3-23.

Morozov, E. (2009). Foreign policy: The brave new world of slacktivism. National Public Radio. Retrieved from http://www.npr.org/templates/story/story.php? storyId=104302141.

Newman, N. (2011). Mainstream media and the distribution of news in the age of social discovery. Reuters Institute for the Study of Journalism. Retrieved from http://reutersinstitute.politics.ox.ac.uk/sites/default/files/Mainstream \%20 media $\% 20$ and $\% 20$ the $\% 20$ distribution $\% 20$ of $\% 20$ news $\% 20$ in $\% 20$ the $\% 20$ age $\% 20$ of $\% 20$ social\%20discovery_0.pdf.

Pager, D. (2007). Marked: Race, crime, and finding work in an era of mass incarceration. Chicago, IL: University of Chicago Press.

Postmes, T., \& Brunsting, S. (2002). Collective action in the age of the Internet: Mass communication and online mobilization. Social Science Computer Review, 20(3), 290-301.

Rogowski, J., \& Cohen, C. (2015). Black Millennials in America: Documenting the experiences, voices and political future of young Black Americans. blackyouthproject.com. Retrieved from http://blackyouthproject.com/wp-content/ uploads/2015/11/BYP-millenials-report-10-27-15-FINAL.pdf.

Rosen, J. (2009). Audience atomization overcome: Why the Internet weakens the authority of the press. PressThink. Retrieved from http://archive.pressthink. org/2009/01/12/atomization.html.

Rucht, D. (2004). The quadruple "A": Media strategies of protest movements since the 1960s. In W. Van De Donk, B. D. Loader, P. G. Nixon, \& D. Rucht, Cyberprotest: New media, citizens and social movements (pp. 25-48). London, UK: Routledge.

Shulman, S. (2009). The case against mass e-mails: Perverse incentives and low quality public participation in U.S. federal rulemaking. Policy and Internet, 1(1), 23-53.

Snow, D. A., Rochford, J. E., Worden, S. K., \& Benford, R. D. (1986). Frame alignment processes, micromobilization, and movement participation. American Sociological Review, 51(4), 464-481. 
Sunstein, C. (2009). Republic.com 2.0. Princeton, NJ: Princeton University Press. Tiara, D. (2014, March 22). The Princeton Xperience [Web log post]. Retrieved from http://darlingtiara.blogspot.com/search?q=princeton.

Williams, B. A., \& Delli Carpini, M. X. (2000). Unchained reaction: The collapse of media gatekeeping and the Clinton-Lewinsky scandal. Journalism, 1(1), 61-85.

Wolfsfeld, G. (1984). Collective political action and media strategy: The case of Yamit. Journal of Conflict Resolution, 28(3), 363-381. 
